\title{
Oxidized Carbon Nanohorns as Novel Sensing Layer for Resistive Humidity Sensor
}

\section{Bogdan Catalin Serban, ${ }^{1, \star}$ Octavian Buiu, ${ }^{1}$ Nicolae Dumbravescu, ${ }^{1}$ Cornel Cobianu, ${ }^{1}$ Viorel Avramescu, ${ }^{1}$ Mihai Brezeanu, ${ }^{2}$ Marius Bumbac ${ }^{3,4}$ and Cristina Mihaela Nicolescu ${ }^{4}$}

\author{
${ }^{1}$ National Institute for Research and Development in Microtechnologies, \\ IMT-Bucharest, 126 A Str Erou Iancu Nicolae, 077190, Voluntari, Ilfov, Romania \\ ${ }^{2}$ University Politehnica of Bucharest, Romania, Faculty of Electronics, Telecommunications and IT, \\ 313 Splaiul Independentei, Sector 6, 060042, Bucharest, Romania \\ ${ }^{3}$ Valahia University of Targoviste, Faculty of Sciences and Arts, Sciences and Advanced Technologies Department, \\ 2 Bd. Carol I, 130024, Targoviste, Dambovita, Romania \\ ${ }^{4}$ Valahia University of Targoviste, Institute of Multidisciplinary Research for Science Technology, \\ 2 Bd. Carol I, 130024, Targoviste, Dambovita Romania \\ * Corresponding author: E-mail: bogdan.serban@imt.ro \\ Tel: +40724284128
}

Received: 07-16-2019

\begin{abstract}
The paper reports the relative humidity $(\mathrm{RH})$ sensing response of a resistive sensor employing oxidized carbon nanohorns - based sensing layer. The sensing layer is deposited on an interdigitated (IDT) structure, comprising a $\mathrm{Si}$ substrate, $\mathrm{a} \mathrm{SiO}_{2}$ layer, and IDT electrodes. The structure exhibits good $\mathrm{RH}$ sensitivity when varying $\mathrm{RH}$ from $0 \%$ up to $90 \%$, either in humid nitrogen or in a humid air environment. The conductivity of the sensing layer decreases, while the $\mathrm{RH}$ level increases. During the interaction with the water molecules (acting as electron donors), the number of holes will decrease and oxidized single-walled carbon nanohorns (SWCNHs), considered normally $p$-type semiconductor, will become more resistive. The sensing mechanism is explained in terms of the Hard Soft Acid Base (HSAB) paradigm, building on the fact that water molecules are hard bases, while oxidized carbon nanohorns can be virtually assimilated with hard acids.
\end{abstract}

Keywords: Humidity sensor; oxidized carbon nanohorns; HSAB principle

\section{Introduction}

Relative humidity (RH) sensors have received increasing attention in the last decades due to their high importance in various areas of environmental control, in both domestic and industrial applications: ${ }^{1,2}$ control of the living environment in buildings, textile and paper industry, food processing, medical field (respirators, incubators, sterilizers), automotive industry (oil humidity control), pharmaceutical processing (quality control of drugs), electronics, meteorology, agriculture, chemical industry (dryers, chemical gas purification, and furnaces), etc. Since RH monitoring is required in fields with various environmen- tal conditions, different types of humidity sensors based on a variety of sensing principles were reported in literature. $^{3}$ Besides ceramic, polymers, polyelectrolytes and semiconducting metal oxides, nanocarbonic materials ${ }^{4-6}$ were also widely used as sensing layers in RH sensors.

Single-walled carbon nanohorns (SWCNHs), consisting of horn-shaped sheath aggregate of graphene sheets, were first reported by Iijima in $1998 .^{7}$ These carbon nanostructures exhibit outstanding properties, such as high conductivity, high dispersibility, large specific surface area, versatile synthesis process (no metal catalyst is involved in their synthesis), availability of high - purity samples, etc. ${ }^{8}$ Thanks to these remarkable features, SWCNHs 
have been widely investigated for different applications, such as catalyst support ${ }^{9}$ or catalyst in the design of fuel cells, ${ }^{10}$ gas storage media, ${ }^{11}$ drug carrier for controlled release, ${ }^{12}$ etc.

However, little information about the sensing capabilities of SWCNHs and their derivatives is available. Sano et al fabricated resistive sensor for ammonia detection at room temperature using SWCNHs as a sensing layer and it was demonstrated that the adsorption of $\mathrm{NH}_{3}$ increases the resistance of the carbonaceous sensing layer. ${ }^{13}$

This study presents for the first time, to our knowledge, the RH sensing response of an oxidized SWCNHs-based sensing layer employed as a resistive sensor.

\section{1. Experimental}

The testing chamber employed for this study accommodated two RH detectors: an oxidized SWCNHs-based sensing structure (depicted as DUT - Device Under Test in Figure 1) and a commercially available Sensirion ${ }^{\circledR} R H$ sensor. The latter was used for double-checking the $\mathrm{RH}$ value indicated by the mass flow controller (MFC)-system. By placing the RH detectors close to each other and to the gas inlet, the two devices were exposed to the same amount of gas flow (in order to provide identical experimental conditions, leading to reliable results). The oxidized SWCNHs (depicted in Figure 2), powder or crystals, $0 \%$ metallic compounds, $10 \%$ graphite, diameter $2-5 \mathrm{~nm}$ (TEM), specific surface area $1300-1400 \mathrm{~m}^{2} / \mathrm{g}$ (BET), were purchased from Sigma Aldrich. ${ }^{14}$ A Keithley 6620 current source was used, ensuring a current variation between 0.01-0.09 A; data was collected and analysed through a Picolog.

For obtaining the SWCNHs-based sensing layer, the following synthesis route was followed:

(i) $0.5 \mathrm{~g}$ of oxidized SWCNHs were dispersed in 25 $\mathrm{mL}$ deionized water and subjected to magnetic stirring for 14400 seconds at room temperature.

(ii) the resulted dispersion was deposited by the "drop casting" method on the sensing structure described below (after previously masking the contact area).

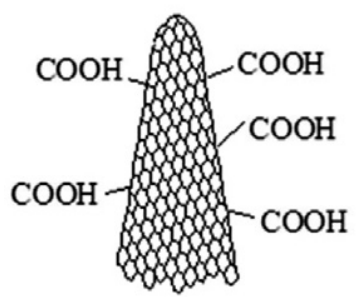

Figure 2. The structure of oxidized SWCNHs.

(iii) the sensing layer was subjected to heat treatment at $150^{\circ} \mathrm{C}$, for 3600 seconds, under vacuum.

The sensing structure is an interdigitated (IDT) structure, manufactured on a $\mathrm{Si}$ substrate $(470 \mu \mathrm{m}$ thickness), covered by a $\mathrm{SiO}_{2}$ layer ( $1 \mu \mathrm{m}$ thickness) (Figure 3 ). The metal stripes of IDT comprise $\mathrm{Cr}$ (10 nm thickness) and $\mathrm{Au}$ (100 nm thickness). The width of the digit is approximately 10 microns, with a $0.6 \mathrm{~mm}$ separation between digits and the bus-bar. In order to avoid increasing the resistance due to the swelling effect, no hydrophilic

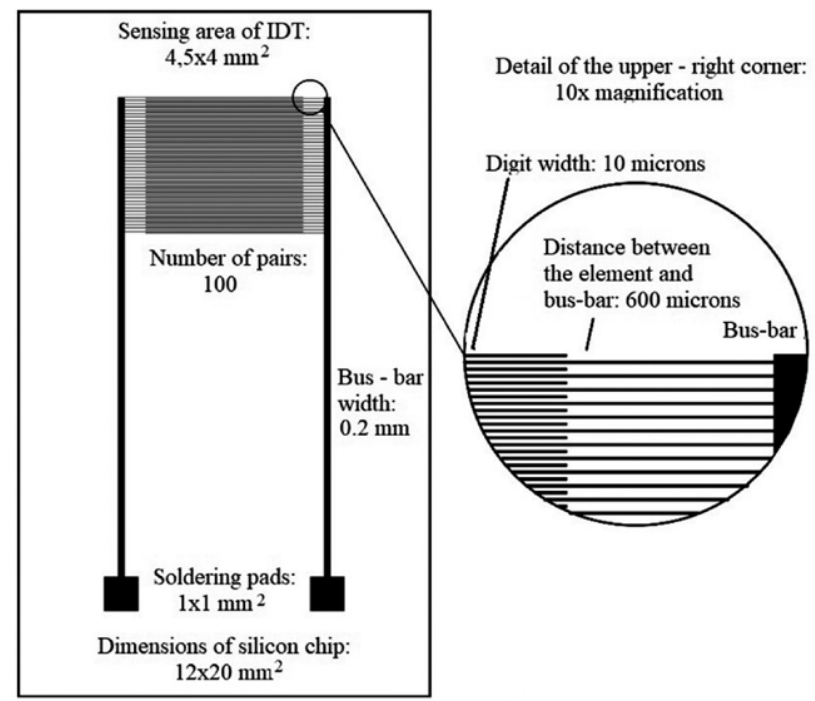

Figure 3. The metal stripes of IDT (Interdigitated structure)

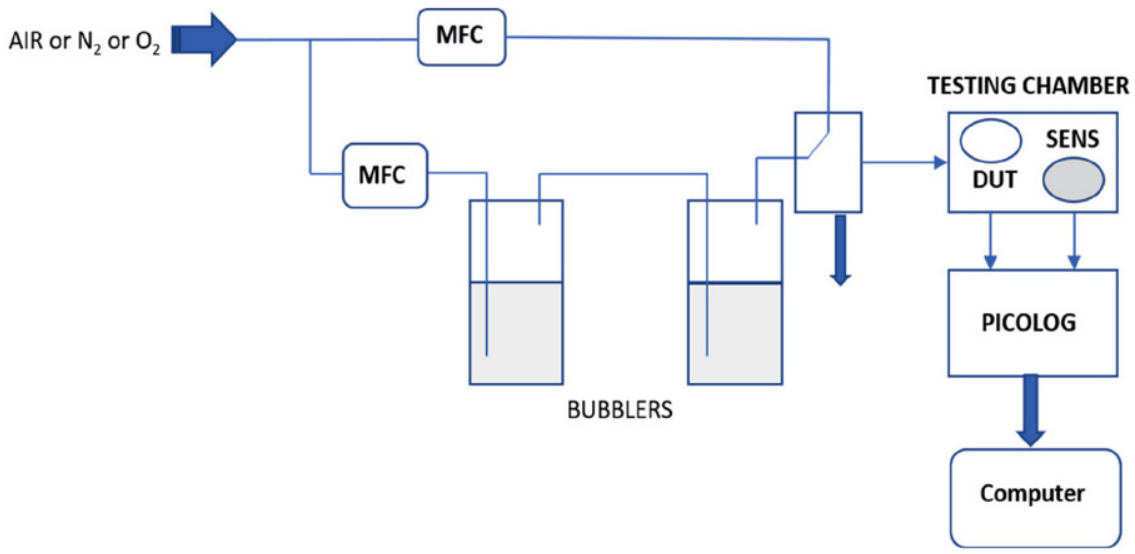

Figure 1. Experimental set-up employed for RH measurements. 
polymer was employed in the composition of the sensing layer.$^{15,16}$

The oxidized SWCNHs were chosen for RH sensing due to their outstanding properties: uniform size, high purity, no metallic compounds, high surface area and high dispersibility in water and organic solvents such as ethanol, and isopropyl alcohol.

\section{Results and Discussion}

The Raman spectrum of the oxidized SWCNHs samples (as purchased) measured at room conditions in two points of the surface are depicted in Figure 4. The measurements were made using a Horiba Jobin Yvone HR800 Raman Instrument, with incident light at $532 \mathrm{~nm}$ and using a power of $45.8 \mathrm{~mW}$. The spectrum exhibits $\mathrm{D}\left(\sim 1315 \mathrm{~cm}^{-1}\right)$, G $\left(\sim 1590 \mathrm{~cm}^{-1}\right)$ and 2D $\left(\sim 2616 \mathrm{~cm}^{-1}\right)$ modes, which are characteristic for $\mathrm{sp}^{2}$ defected carbon nanomaterials. The $\mathrm{G}$ mode corresponds to tangential atomic vibrations of the graphite mesh, while the $\mathrm{D}$ mode reveals defect carbon states different from the graphite mesh. Two types of topological distorsions are responsible for the $\mathrm{D}$ band origination in oxidized carbon nanohorns Raman spectrum: pentagons to generate the characteristic conical-like architecture and layer folding. ${ }^{17,18}$ Moreover, oxidation partially affects the sample and increases defectiveness. ${ }^{19}$ Comparing the Raman spectra of oxidized SWNHs, pristine SWNHs and SWNTs, we noticed that oxidized SWN$\mathrm{Hs}$ exhibit a D band with higher intensity which is in agreement with the literature data, ${ }^{20}$ while the characteristic $2 \mathrm{D}$ band varies with the $\mathrm{ABAB}$ stacking of graphene layers. ${ }^{21}$

The RH response of the sensor was investigated by applying a current between the two electrodes and measuring the voltage drop when varying the $\mathrm{RH}$ from $0 \%$ up

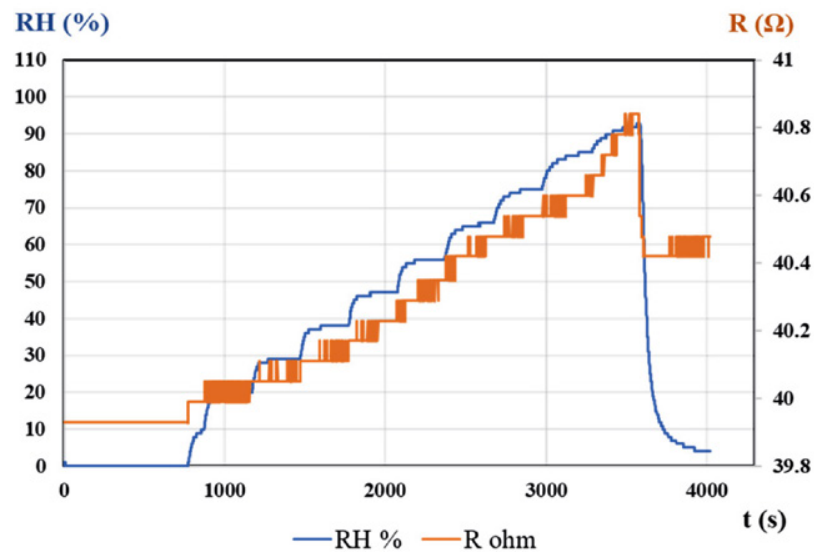

Figure 5. The RH response of the oxidized SWCNHs-based sensor in humid nitrogen (red curve) vs. the $\mathrm{RH}$ response of the Sensirion RH sensor (blue curve)

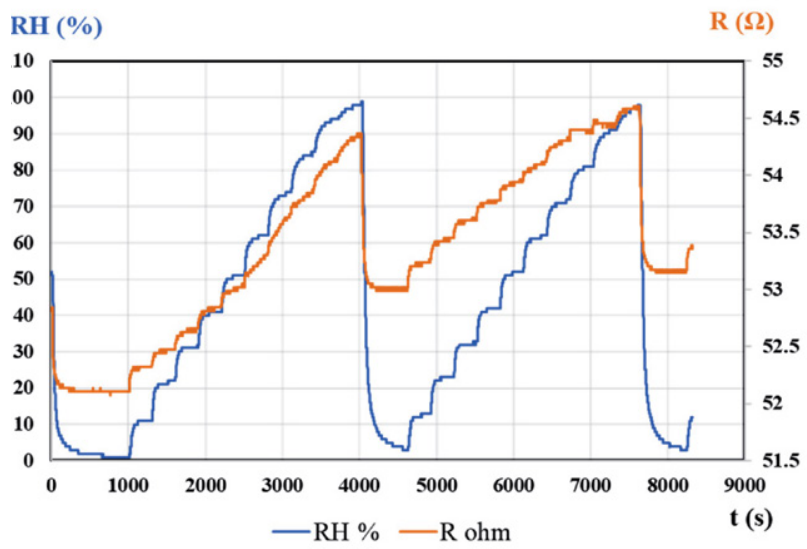

Figure 6. The RH response of the oxidized SWCNHs-based sensor in humid air (red curve) vs the RH response of the Sensirion RH sensor (blue curve)

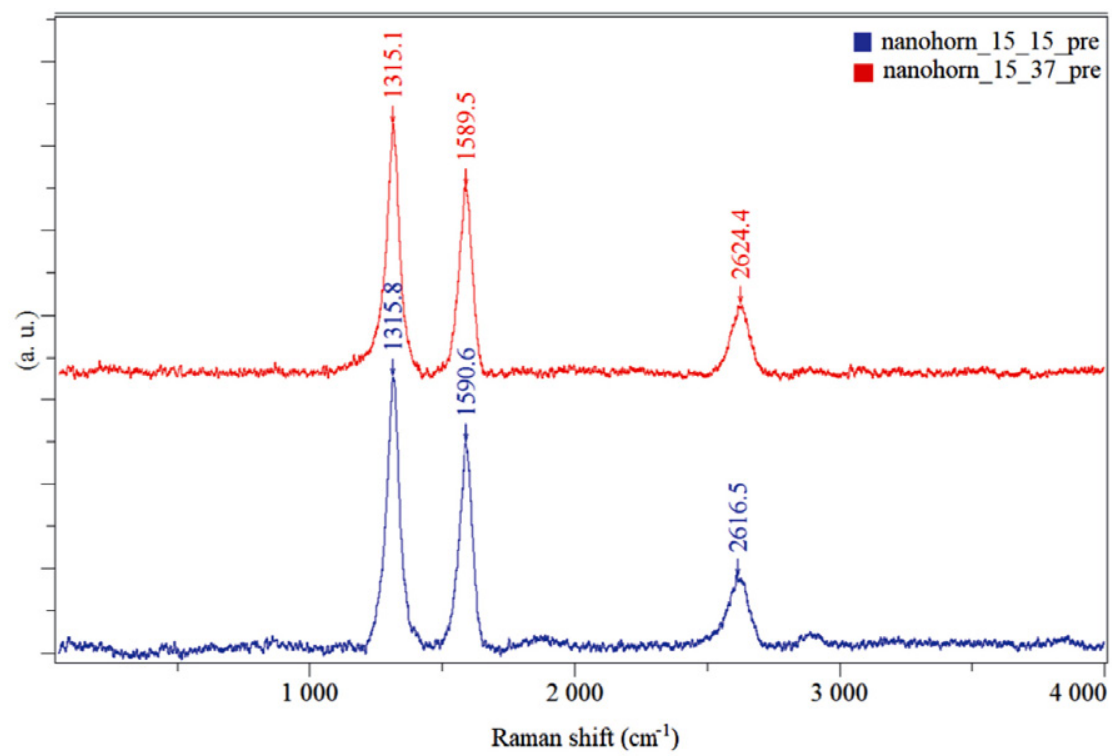

Figure 4. Raman spectra for oxidized carbon nanohorns. 
to $90 \%$, both in humid nitrogen environment (Figure 5) and in the humid air (Figure 6). The resistance of the carbonaceous sensing layer increases when $\mathrm{RH}$ increases.

The overall linearity of the oxidized SWCNHs-based sensor response - in both humid nitrogen and humid air,

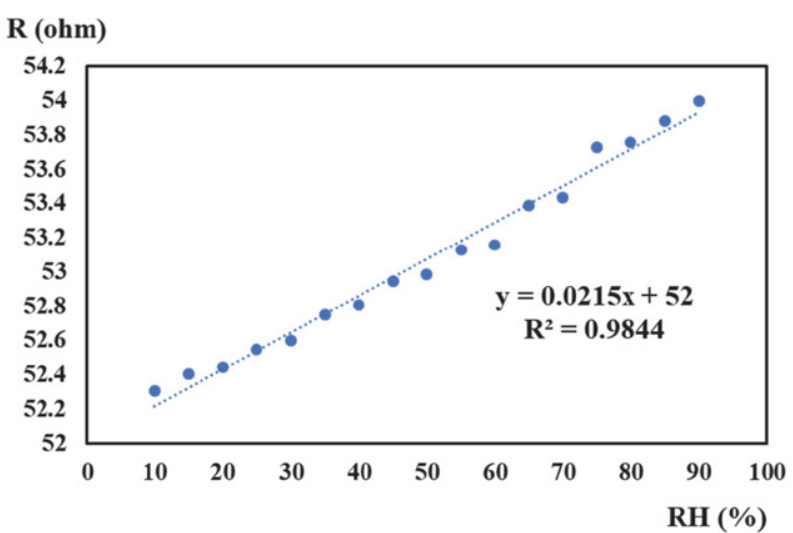

Figure 7. The transfer function of the sensor in humid air $(\mathrm{RH}=$ $10 \%-90 \%)$

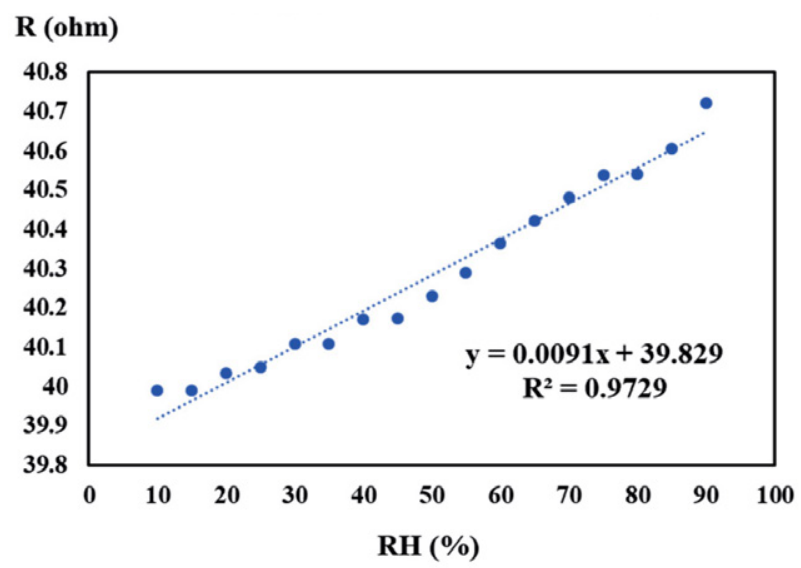

Figure 8. The transfer function of the sensor in humid nitrogen $(\mathrm{RH}$ $=10 \%-90 \%) \mathrm{w}$ when varying $\mathrm{RH}$ from $10 \%$ to $90 \%$ - is very good, as shown in Figures 7 and 8.

In terms of linearity, the $\mathrm{RH}$ response in humid air is better than in humid nitrogen $\left(\mathrm{R}^{2}=0.9844\right.$ in humid air versus $\mathrm{R}^{2}=0.9729$ for humid nitrogen). Sensitivity calculated when varying $\mathrm{RH}$ from $10 \%$ to $90 \%$, as the slope of the trendline, is approximately two times higher in humid air compared to humid nitrogen $(21 \mathrm{~m} \Omega / \mathrm{RH}$ unit compared to $9.1 \mathrm{~m} \Omega / \mathrm{RH}$ unit).

If the sensitivity $(\mathrm{S})$ is evaluated by considering the variation of the sensor resistance with $\mathrm{RH}$, i. e.:

$$
\mathrm{S}(x)=\frac{R_{10}-R_{\chi}}{R H_{x}-R H_{10}}
$$

then it can be shown that $\mathrm{S}$ is, in general, increasing with $\mathrm{RH}$; the lowest value of $\mathrm{S}(0.0133)$ is obtained at $\mathrm{RH}=20 \%$, while the maximum value $(0.021)$ is reached for $\mathrm{RH}=$ $75 \%$. These results are in agreement with the literatura data, comparable sensitivities being obtained using other type of carbonaceous materials as sensing layers. ${ }^{22}$

The response time $\left(t_{\mathrm{r}}\right)$ of the humidity sensor represents a key performance parameter; if $R(\mathrm{t})$ is the response of the device in time, the $t_{\mathrm{r}}$ can be evaluated as:

$$
t_{r}=t_{90}-t_{10}
$$

where $t_{90}$ and $t_{10}$ represent the moments in time where the response $R(\mathrm{t})$ is reaching $90 \%$ and $10 \%$, respectively from the total variation of the sensor's resistance. ${ }^{22}$ The response time of the oxidized carbon nanohorns based sensor in humid air is $3 \mathrm{~s}$, while in humid nitrogen is $8 \mathrm{~s}$. A comparison with the response times humidity sensors based on other nanocarbonic materials used as sensing layers are shown in Table 1.

In terms of drift, the performance of the novel sensor - in absolute terms - was worse that of the Sensirion ${ }^{\circledR} \mathrm{RH}$ sensor. In the case of the novel sensor described here, the hysteresis could be attributed to the water molecules pen-

\begin{tabular}{|c|c|c|}
\hline Type of sensing material & Response time(seconds) & Reference \\
\hline Multi-Walled Carbon Nanotubes (MWCNTs) & $120-180$ & {$[23]$} \\
\hline Suspended Carbon Nanotubes & 12 & {$[24]$} \\
\hline MWCNTs / Polyacrylic acid ( $1: 4 \mathrm{w} / \mathrm{w})$ & 670 & {$[25]$} \\
\hline MWCNTs/Polyvinylpirrolidone & 15 & {$[26]$} \\
\hline Single-Walled Carbon Nanotubes(SWCNTs)/ Polyvinyl alcohol $(1: 5 \mathrm{w} / \mathrm{w})$ & 40 & {$[27]$} \\
\hline $3 \mathrm{wt} \%$ MWCNTs in a Polyimide & $<5$ & {$[28]$} \\
\hline Graphene oxide (GO) & 2 & [29] \\
\hline $\mathrm{GO}$ & $30 \mathrm{~ms}$ & {$[30]$} \\
\hline $\mathrm{GO} / \mathrm{MoS}_{2}$ & $\begin{array}{c}\text { (fastest humidity sensor } \\
\text { known at present) } \\
\text { from } 116 \text { to } 17 \\
\text { (depending on the } \\
\text { specific composition) }\end{array}$ & {$[31]$} \\
\hline
\end{tabular}

Table 1. Response times humidity sensors based on carbonaceous materials used as sensing layers 
etrating deep into the hydrophilic sensitive film at higher relative humidity. Due to the presence of hydrophilic carboxyl groups in oxidized SWCNHs and their propensity for forming hydrogen bonds with water molecules, the sensing layer could adsorb a significant number of molecules which eventually induce their condensation in the proximity of carboxylic groups.

Given the specifics of the sensing materials used, two distinct sensing mechanisms can be considered at first glance. The first one takes into account the dissociation of water. The adsorbed water molecules on oxidized carbon nanohorns surface may dissociate to $\mathrm{H}^{+}$and $\mathrm{OH}^{-}$ions at the edges of carbonaceous nanomaterial, similar to what is observed for other nanocarbonic materials such as graphene oxide samples. ${ }^{32}$ The protons generated by the water dissociation process may tunnel from one water molecule to another through hydrogen bonding, increasing the overall electrical conductivity of the sensitive film. The second mechanism takes into accounts the fact that oxidized SWCNHs are $p$-type semiconducting material. When interacting, the water molecules donate their electrons pairs, thus decreasing the number of the holes in oxidized SWCNHs. Therefore, the conductivity of the oxidized SWCNHs-based sensing layer decreases.

Without completely excluding the first mechanism, it is clear that the second effect dominates, and the tandem oxidized SWCNHs (acting as a p-type semiconductor) / water (electrons release) is the decisive factor for the overall decreasing resistance of the sensing layer.

Better sensitivity of oxidized SWCNHs in humid air in comparison with humid nitrogen is not surprising at all. This result is in agreement with those reported by Watts et al. ${ }^{33}$ The vast majority of $\mathrm{O}_{2}$ molecules present in the humid air are preferentially absorbed onto the polar carboxyl groups on the oxidized carbon nanohorns. The oxygen molecules are slightly polarizable (i.e. induced dipole) and can generate hydrogen bonding with the hydroxide $(-\mathrm{OH})$ on the carboxyl group. Thus, the electron-withdrawing effect of the carboxyl group decreases and hence slightly decreases the hole carrier concentration on the oxidized SWCNHs, yielding to a minor overall increase in resistance for the oxidized SWCNHs. Even though oxygen molecules physisorption yields to an antithetical electrical response, the presence of carboxylic groups onto the backbone of SWCNHs is a key structural feature and formation of the hydrogen bond to each carboxyl group is a dominant factor.

\section{1. Extension of HSAB Concept to Oxidized Carbon Nanohorn- Based Humidity Sensor}

Recently, the Hard-Soft Acid Base (HSAB) concept was used in gas sensing research and development. ${ }^{34,35}$ Based on this theory, many sensitive films were synthesized and used for detecting different species, such as sul- phur dioxide, ${ }^{36}$ carbon dioxide, ${ }^{37}$ nitrogen dioxide, ${ }^{38}$ ammonia, ${ }^{39}$ benzene. ${ }^{40}$

The HSAB concept operates with Lewis bases and acids; a molecular species donating a pair of electrons are classified as bases, while molecular entities accepting a pair of electrons are classified as acids. Based on different properties such as HOMO energy level, polarizability, the dimension of ionic radii, electronegativity, charge, Pearson categorizes Lewis' bases and acids into hard, borderline and soft.

The HSAB theory postulates that a hard base prefers to bind to a hard acid, whereas a soft base tends to interact with a soft acid. Correspondingly, a borderline base tends to bond to a borderline acid. From the HSAB theory point of view, water is classified as a hard base, while oxidized SWCNHs are hard acids.

Considering, on one hand, the electronic interaction between water molecules and hard acid species and, on the other hand, the conductive properties of carbon nanomaterials, the following question arises: can the HSAB concept explain the moisture sensing capabilities by oxidized SWCNHs-based sensing layers?

If one changes the paradigm and considers that, by analogy, the holes in various carbon nanomaterials are Lewis sites, then one can conclude that their exposure to hard bases (such as water) could change their electrical resistance. Thus, in the case of p-type nanocarbonic layers (such as oxidized SWCNHs), water molecules are adsorbed on their surface and donate electrons to them. As a consequence, the number of holes in oxidized SWCNHs decreases, a phenomenon which leads to increasing the difference between its Fermi level and its valence band. This determines an increase of the electrical resistance, which is exactly the result reported in this paper.

Several results reported in the literature are also in agreement with this statement. RH sensors based on multi-walled carbon nanotubes thin films ${ }^{41}$ CMOS inkjet-printed graphene, ${ }^{42}$ reduced graphene oxide/polymer nanocomposite film ${ }^{43}$ are just a few examples.

\section{Conclusions}

A resistive sensor for $\mathrm{RH}$ monitoring employing oxidized SWCNHs as a novel sensing layer was fabricated. The sensing capability of the sensitive film was investigated when varying between $10 \%$ up to $90 \%$ in both humid nitrogen environment and humid air. It was demonstrated that the conductivity of the sensing layer decreases, while $\mathrm{RH}$ increases. The sensitivity of oxidized SWCNHs as sensing layer is approximately two times higher in humid air compared to humid nitrogen and this result was explained through the presence of the carboxylic groups. From the sensing mechanism point of view, interaction with the water molecules (which act as electron donors) decreases the number of holes and oxidized SWCNHs ( $p$-type semiconductor) becomes more resistive. The sens- 
ing mechanism was discussed, also, in terms of HSAB concept based on the fact that water molecules are hard bases and considering the holes as hard acids. Due to its excellent sensitivity and fast response time, oxidized SWCNHs is a promising material for resistive $\mathrm{RH}$ monitoring. It is clear that optimized degree of hydrophilicity (an "ideal" number of carboxylic groups onto the surface of SWCN$\mathrm{Hs}$ ) is a key factor in order to obtain a sensor with better sensitivity, high response time and low hysteresis.

These types of oxidized carbon nanohorns can be synthesized by heat treatment in air, ${ }^{44}$ acid treatment, ${ }^{45}$ and $\mathrm{H}_{2} \mathrm{O}_{2}$ treatment of pristine SWCNHs. ${ }^{46}$ Last but not least, hydrophilization of carbon nanohorns, as -grown, can be performed using different treatment in plasma oxygen, plasma water by adjusting the exposure time and/or power source.

Regarding the future work, It is expected that composites of the oxidized carbon nanohorns with different polymers will increase the overall performance of the sensor. The interfacial heterojunctions between oxidized carbonaceous material and a hydrophilic polymer such as polyvinylpirrolidone (PVP) can strongly influence the sensitivity and response/recovery times of the sensors.

\section{Acknowledgment}

Authors from IMT Bucharest do acknowledge the financial support of Romanian Ministry for Research and Innovation through contracts 14N/2019 - MICRO-NANO-SIS PLUS and 42/2019 (PCCDI) - NANOCARBON+. Also, the support of Dr. Florin Comanescu in performing the Raman spectroscopy measurements is greatly acknowledged.

\section{References}

1. Z. Chen, C. Lu, C., Sensors Letters, 2005, 3, 274-295.

DOI:10.1166/sl.2005.045

2. E. Traversa, Sensors \& Actuators B: Chemical, 1995, 23, 135156. DOI:10.1016/0925-4005(94)01268-M

3. C. Y. Lee, G. B. Lee, Sensors Letters, 2005, 3, 1-15.

4. Z. M. Rittersma, Sensors \& Actuators A: Physical, 2002, 96, 196-210. DOI:10.1016/S0924-4247(01)00788-9

5. C. Cobianu, B. C. Serban, M. Mihaila, US Patent Number 8,479,560, date of patent July 9, 2013.

6. H. Bi, K. Yin, X. Xie, J. Ji, S. Wan, L. Sun, L., M. S. Dresselhaus, Sci. Rep., 2013, 3, 2714.

7. S. Iijima, M. Yudasaka, R. Yamada, S. Bandow, K. Suenaga, F. Kokai, K. Takahashi, Chem. Phys. Lett., 1999, 309, 165-170.

DOI:10.1016/S0009-2614(99)00642-9

8. N. Karousis, I. Suarez-Martinez, C. P. Ewels, N. Tagmatarchis, Chem. Rev., 2016, 116, 4850-4883.

DOI:10.1021/acs.chemrev.5b00611

9. T. Yoshitake, Y. Shimakawa, S. Kuroshima, H. Kimura, T. Ichihashi, Y. Kubo, S. Iijima, Physica B, 2002, 323, 124-126.

DOI:10.1016/S0921-4526(02)00871-2
10. L. Zhang, N. Zheng, A. Gao, C. Zhu, Z. Wang, Y. Wang, Y. Liu, J. Power Sources, 2012, 220, 449-454.

DOI:10.1016/j.jpowsour.2012.08.009

11. E. Bekyarova, K. Murata, M. Yudasaka, D. Kasuya, S. Iijima, H. Tanaka, K. Kaneko, J. Phys. Chem. B, 2003, 107, 4681-4684. DOI:10.1021/jp0278263

12. J. Xu, M. Yudasaka, S. Kouraba, M. Sekido, Y. Yamamoto, S. Iijima, Chem. Phys. Lett., 2008, 461, 189-192.

DOI:10.1016/j.cplett.2008.06.077

13. N. Sano, M. Kinugasa, F. Otsuki, J. Suehiro, Adv. Powder Technol., 2007, 18, 455-466.

DOI:10.1163/156855207781389447

14. Sigma-Aldrich, Carbon nanohorns, oxidized, 804126, https:/www.sigmaaldrich.com/catalog/product/aldrich/ 804126?lang=en\&region=CZ, accessed June 2019.

15. W. Li, F. Xu, L. Sun, W. Liu, Y. Qiu, Sensors \& Actuators B: Chemical, 2016, 230, $528-535$.

DOI:10.1016/j.snb.2016.02.108

16. T. Fei, K. Jiang, F. Jiang, R. Mu, T. Zhang, J. of Appl. Polymer Sci., 2014, 131, 39726. DOI:10.1002/app.39726

17. T. Yamaguchi, S. Bandow and S. Iijima, Chem. Phys. Lett., 2004, 389, 181-185. DOI:10.1016/j.cplett.2004.03.068

18. A. C. Ferrari and J. Robertson, Phys. Rev. B, 2000, 61, 1409514107. DOI:10.1103/PhysRevB.61.14095

19. M. Peña-Álvarez, E del Corro, F. Langa, V.G. Baonza, M. Taravillo, RSC Advances, 2016, 6(55), 49543-49550. DOI:10.1039/C5RA27162B

20. C. T. Cioff, Functionalization and application of carbon nanohorns and carbon onions, $\mathrm{PhD}$ thesis (2008). https://www. openstarts.units.it/handle/10077/2614

21. N. Larouche and B. L. Stansfield, Carbon, 2010, 48, 620-629. DOI:10.1016/j.carbon.2009.10.002

22. J.M Tulliani, B. Inserra, and D. Ziegler. Micromachines 10.4, 2019, 232. DOI: $10.3390 / \mathrm{mi} 10040232$

23. O. K.Varghese, P. D. Kichambre, D. Gong, K. G. Ong, E. C. Dickey, C. A. Grimes, Sensors \& Actuators B: Chemical 2001, 81, 32-41. DOI:10.1016/S0925-4005(01)00923-6

24. S. Arunachalam, R. Izquierdo, F. Nabki, Sensors 2019, 19(3), 680. DOI: $10.3390 / \mathrm{s} 19030680$

25. J. Lee, D. Cho, Y. Jeong, Solid-State Electronics 2013, 87, 8084. DOI:10.1016/j.sse.2013.05.001

26. X. Pan, Q. Xue J. Zhang, Q. Guo, Y. Jin, W. Lu, X. Li, C. Ling. Adv. Mater. Interfaces. 2016, 3, 1-7. DOI:10.1002/admi.201600153

27. G. Zhou , J. H. Byun , Y. Oh, B. -M. Jung, H. -J. Cha, D. G. Seong, M. K. Um, S. Hyun, T. W. Chou, ACS Appl. Mater. Interfaces. 2017, 9, 4788-4797. DOI:10.1021/acsami.6b12448

28. Q. Y. Tang, Y. C. Chan, K. Zhang, Sens. Actuators B Chem. 2011, 152, 99-106. DOI:10.1016/j.snb.2010.09.016

29. L. Guo ,H. -B. Jiang, R. -Q. Shao, Y. -L. Zhang, S. -Q. Xie,J. -N. Wang, X.-B. Li, F. Jiang, Q. -D. Chen, T. Zhang, Carbon 2012, 50, 1667-1673. DOI:10.1016/j.carbon.2011.12.011

30. S. Borini, R. White, M. Astly, R. White, D. Wei, S. Haque, E. Spigone, N. Harris, ACS Nano 2013, 12, 11166-11173. DOI: $10.1021 / \mathrm{nn} 404889 \mathrm{~b}$

31. S. Y. Park, J. E. Lee, Y. H. Kim, J. J.Kim, Y. -S. Shim , S. Y. 
Kim , M. H. Lee, H. W. Jang, Sensors \& Actuators B: Chemical 2018, 258, 775-782. DOI:10.1016/j.snb.2017.11.176

32. H. Bi, K. Yin, X. Xie, J. Ji, S. Wan, L. Sun, M. S. Dresselhaus, Scientific Reports, 2013, 3, 2714.

33. P. C. P. Watts, N. Mureau, Z. Tang, Y. Miyajima, J. D. Carey, S. R. P. Silva, Nanotechnology, 2007, 18, 175701.

DOI:10.1088/0957-4484/18/17/175701

34. R. G. Pearson, J. Am. Chem. Soc., 1963, 85, 3533-3539. DOI:10.1021/ja00905a001

35. R. G. Pearson, J. Am. Chem. Soc., 1988, 110, 7684-7690. DOI:10.1021/ja00231a017

36. B. C. Serban, C. P. Cobianu, M. N. Mihaila, V. G. Dumitru, U.S. Patent Number 8,609,427, date of patent December 17, 2013.

37. B. C. Serban, A. K. Sarin Kumar, M. Brezeanu, C. P. Cobianu, O. Buiu, C. Bostan, N. Varachiu, S. Costea, Romanian Journal of Inf. Sci. and Tech., 2011, 14, $222-231$.

38. B. C. Serban, C. P. Cobianu, M. N. Mihaila, V. G. Dumitru, O. Buiu, U.S. Patent Number 8,563,319, date of patent October 22, 2013.

39. B. C. Serban, O. Buiu, C. P. Cobianu, M. Brezeanu, M. Bum- bac, C. M. Nicolescu, Acta Chim. Slov., 2018, 65, 1014 - 1021. DOI:10.17344/acsi.2018.4564

40. B. C. Serban, O. Buiu, M. Brezeanu, C. P. Cobianu, C. G. Bostan, C. Diaconu, US Patent Number 10,254,217, date of patent April 9, 2019.

41. C. L. Cao, C. G. Hu, L. Fang, S. X. Wang, Y. S. Tian, and C. Y. Pan, Journal of Nanomaterials 2011 (2011): 5.

42. S. Santra, G. Hu, R. C. T. Howe, A. De Luca, S. Z Ali, F. Udrea, J. W. Gardner, S. K. Ray, P. K. Guha, T. Hasan, Sci. Rep., 2015, 5, 17374. DOI:10.1038/srep17374

43. D. Zhang, J. Tong, B. Xia, Sensors \& Actuators B: Chemical, 2014, 197, 66-72. DOI:10.1016/j.snb.2014.02.078

44. J. Fan, M. Yudasaka, J. Miyawaki, K. Ajima, K. Murata, S. Iijima, J. Phys. Chem. B 2006, 110, 1587-1591.

DOI:10.1021/jp0538870

45. R. Yuge, T. Ichihashi, Y. Shimakawa, Y. Kubo, M. Yudasaka, S. Iijima, Adv. Mater. 2004, 16, 1420.

DOI:10.1002/adma.200400130

46. M. Zhang, M. Yudasaka, K. Ajima, J. Miyawaki, S. Iijima, ACS Nano 2007, 1, 265. DOI:10.1021/nn700130f

\section{Povzetek}

V prispevku predstavljamo odziv senzorja relativne vlažnosti, ki uporablja senzorsko plast na osnovi oksidiranih ogljikovih nanorogov (single-walled carbon nanohorns, SWCNH). Senzorska plast je nanesena na interdigitalno (IDT) strukturo, ki vsebuje substrat $\mathrm{Si}$, plast $\mathrm{SiO}_{2}$ in IDT elektrode. Senzor ima dobro občutliivost za merjenje relativne vlažnosti v območju od $0 \%$ do $90 \%$, bodisi v vlažnem dušiku, bodisi v okolju vlažnega zraka. Prevodnost senzorske plasti se zmanjšuje, medtem ko se raven relativne vlažnosti povečuje. Med interakcijo z molekulami vode, ki delujejo kot donorji elektronov, se bo število odprtin zmanjšalo in upornost oksidiranih ogljikovih nanorogov, ki jih običajno uvrščamo med polprevodnike tipa $\mathrm{p}$, se bo povečala. Mehanizem zaznavanja smo razložili s teorijo trdih in mehkih kislin in baz (HSAB), ki temelji na dejstvu, da so molekule vode trde baze, oksidirane ogljikove nanorogove pa lahko ponazorimo s trdimi kislinami.

Except when otherwise noted, articles in this journal are published under the terms and conditions of the Creative Commons Attribution 4.0 International License 